\title{
The Effect of Haematological Parameters on Overall Survival in Advanced Stage Non Small Cell Lung Cancer
}

\author{
Arzu OGUZ ${ }^{1}$, Dilsen COLAK ${ }^{2}$, Ugur ERSOY ${ }^{2}$, Inanc G. IMAMOGLU ${ }^{2}$, \\ Mustafa ALTINBAS ${ }^{2}$, Dilek UNAL ${ }^{3}$, Gokmen ZARARSIZ ${ }^{4}$
}

\footnotetext{
${ }^{1}$ Baskent University Faculty of Medicine, Department of Medical Oncology, Ankara

${ }^{2}$ Diskapi Yildirim Beyazit Training and Research Hospital, Medical Oncology Clinic, Ankara

${ }^{3}$ Kayseri Training and Research Hospital, Department of Radiation Oncology Clinic, Kayseri

${ }^{4}$ Hacettepe University Faculty of Medicine, Department of Biostatistics, Ankara, TURKEY
}

\begin{abstract}
In this study, we aimed to evaluate the prognostic value of pretreatment blood count values, particularly WBC counts, in patients with advanced non-small cell lung cancer (NSCLC). The records of 186 patients with advanced stage (stage IIIB and IV) NSCLC were assessed retrospectively. Patients were divided into 3 subgroups according to WBC levels; $\leq 10000 / \mathrm{mm}^{3}$ as Group $1,>10000$ and $\leq 15000 / \mathrm{mm}^{3}$ as Group 2 and >15000/(mm ${ }^{3}$ as Group 3. Patient and tumor characteristics as well as outcomes in terms of overall survival (OS) were evaluated. Median OS was 13.3 months in the whole population, 25.7 months in stage IIIB and 8.9 months in stage IV patients. According to the pretreatment leukocyte values, median OS was 17.9 months in Group 1, 11.2 months in Group 2 and 8.4 months in Group 3 ( $p=0.003$ ). Median OS values in WBC groups according to stages IIIB and IV were significantly different $(p<0.001)$. In multivariate analyses, ECOG-PS 2 or 3, stage IV disease, anemia and high WBC levels were associated with poorer OS. In this study, higher pretreatment WBC levels were associated with poorer OS in patients with advanced stage NSCLC. Pretreatment WBC counts may represent a simple prognostic factor and may aid in tailoring treatment in patients with advanced NSCLC.
\end{abstract}

Keywords: Anemia,Leukocytosis, Non Small cell lung cancer, Survival, Thrombocytosis

\section{ÖZET}

\section{İleri Evre Küçük Hücreli Dışı Akciğer Kanserinde Hematolojik Parametreler ve Sağkalım illişkisi}

Çalışmamızda, ileri evre küçük hücreli dışı akciğer karsinomu tanısı ile takip ve tedavisi yapılmış olan vakalarda tanı anındaki hematolojik parametreler özellikle de artan beyaz küre değerleri ile sağkalım arasındaki ilişkinin değerlendirilmesi amaçlanmıştır. Evre 3B ve 4 küçük hücreli dışı akciğer karsinomu tanısı almış toplam 186 vakanın dosyaları retrospektif olarak değerlendirildi. Hastalar başlangıç lökosit değerlerine göre 3 alt gruba ayrıldı; toplam lökosit sayısı $\leq 10000 / \mathrm{mm}^{3}$ Grup 1, 10000- $\leq 15000 / \mathrm{mm}^{3}$ Grup 2, >15000 Grup 3. Hasta ve tümör özelliklerine ek olarak hematolojik parametreler ile genel sağkalım ilişkisi değerlendirildi. Ortanca sağkalım tüm hasta grubunda 13,3 ay; evre IIIB hastalarda 25,7 ay ve evre IV olanlarda 8,9 ay olarak hesaplandı. Tedavi öncesi lökosit değerlerine göre Grup 1'de ortanca sağkalım 17,9 ay, Grup 2'de 11,2 ay, Grup 3'te ise 8,4 ay idi ( $p=0.003)$. Evreye göre lökosit gruplarının sağkalımları arasında da anlamlı farklılık mevcuttu ( $p<0.001)$. Çok değişkenli analizde ECOG-PS 2-3, evre IV hastalık ve tanıdaki hemoglobin ve lökosit değerleri ile sağkalım arasında anlamlı ilişki saptandı. Çalışmamızda tanı anındaki yüksek beyaz küre değerlerinin ileri evre küçük hücreli dışı akciğer karsinomunda sağkalım üzerinde olumsuz etkisi gösterilmiştir. İleri evre vakalarda tanı anındaki lökosit sayısı, tedavi planı yapıırken yol gösterebilecek basit ve pratik bir prognostik faktör olarak değerlendirilebilir.

Anahtar Kelimeler: Anemi, Lökositoz, Küçük hücreli dışı akciğer kanseri, Sağkalım, Trombositoz 


\section{INTRODUCTION}

Lung cancer is still the leading cause of cancer-related death worldwide. ${ }^{1}$ Five years' survival is about $15.9 \% .^{2}$ Non small cell lung cancer (NSCLC) accounts for about $85 \%$ of all lung cancer cases. The majority of NSCLC patients are diagnosed at advanced stage, only about $15-20 \%$ being early stage at diagnosis. Recurrence risk is high even in early stage disease. ${ }^{3}$ Best defined prognostic factors for advanced NSCLC are disease stage, ECOG performance status (PS), gender and the presence of weight loss., Prognosis of patients with advanced disease is mostly ominous but also variable among different individuals, therefore recent studies began to search for new prognostic factors. ${ }^{6,7}$ At present, most research has focused on genetic predictive and/or prognostic factors such as EGFR, bcl-2 and K-ras mutations, ERCC-1 and RRM-1 expression, EML4-ALK translocation, most of which are not applicable in many centers and are often expensive.

Increased white blood cell (WBC) count can be found in patients with cancer either at the time of diagnosis or during follow-up period and can be secondary to infections, chronic steroid usage or bone marrow metastases. ${ }^{8}$ However, patients with NSCLC may sometimes have leukocytosis distinct from these conditions, described as tumor-related leucocytosis, a condition which is caused mainly by unregulated autonomous production of hematopoietic cytokines such as G-CSF, GM-CSF and IL-6. ${ }^{9} 10$ Previous studies showed leukocytosis to be secondary to the production of G-CSF by the tumor, and this was an epiphenomenon of the biologic aggressiveness of the tumor. ${ }^{11}$ The prognostic importance of blood count findings were evaluated by some large series previously but the results were contradictory. ${ }^{12-14}$

In this study, we aimed to evaluate the prognostic value of pretreatment blood count values, particularly WBC counts, in patients with advanced NSCLC.

\section{MATERIAL AND METHODS}

The records of 220 patients with histologically confirmed stage IIIB and IV NSCLC were reviewed retrospectively. Patients with active infection, bone marrow metastases or history of steroid use at the time of diagnosis were excluded. In total 186 patients were included in this study. Patient and tumor characteristics including ECOG-PS and disease stage as well as pre-treatment WBC count, hemoglobin ( $\mathrm{Hb})$ and platelet (plt) levels were recorded. Patients were grouped as anemic if $\mathrm{Hb}$ level was $<12 \mathrm{~g} / \mathrm{dl}$ for females and $<13 \mathrm{~g} / \mathrm{dl}$ for males. Thrombocytosis was defined as platelet count $>373000 / \mathrm{mm}^{3}$ according to the reference limits in our laboratory.

Shapiro-Wilk's test results, histogram and q-q plots were examined to assess the data homogeneity. Oneway analysis of variance, Kruskal-Wallis $\mathrm{H}$ test and Mann-Whitney U tests were used to compare differences between continous variables and Chi-Square analysis were used to compare differences between categorical variables. Values are expressed as $\mathrm{n}(\%)$, mean \pm SD or median(25th -75 th percentiles). Moreover, Kaplan-Meier curves were drawn to obtain survival probabilities and log rank test was used to compare these curves between groups. Univariate and multiple cox regression analysis were also applied and hazard ratios were calculated with $95 \%$ confidence intervals. For overdispersed variables, z-scores were calculated and these transformed variables were used instead of raw values. Significant variables at $\mathrm{p}<$ 0.25 were included to multiple model and backward stepwise selection was applied at 0.10 stringency level. Analyses were conducted using R 2.15.2 software. $\mathrm{P}<0.05$ was considered statistically significant.

\section{RESULTS}

Median age was 63 (range 37-88). Twenty-five $(13.4 \%)$ patients were female and $161(86.6 \%)$ were male. A history of smoking was present in $85.7 \%$ of the patients. Histological subtype was adenocarcinomas in 64 patients $(34.4 \%)$, squamous cell carcinoma in 85 patients (45.7\%), unspecified (NOS) type in 31 patients $(16.7 \%)$. The remaining 5 cases $(2.7 \%)$ had large cell and bronchoalvelolar subtype. Disease stage was IIIB in 66 (35.5\%) and IV in 120 patients $(64.5 \%)$.

Median OS was 13.3 months (95\% CI: 10.1-16.6) in the whole population. Overall survival was significantly longer in patients with stage IIIB disease than those with stage IV disease [25.7 months (95\%CI:14.9-36.5) vs 8.9 months (95\% CI: 6.9-10.9), respectively, $\mathrm{p}<0.001]$.

ECOG-PS of the patients were 0 in $56(30.1 \%), 1$ in $86(46.2 \%), 2$ in $31(16.7 \%)$ and 3 in $13(7.0 \%)$ of the patients at diagnosis. Median OS was 18.8 months for the patients with a PS of 0,15.4 months for PS of 1, 4.6 months for PS of 2 and 4.0 months for PS of 3 . 
Table 1. Median levels of pretreatment blood counts

\begin{tabular}{|llll|}
\hline & \multicolumn{2}{c}{ Stage } & p \\
\cline { 2 - 3 } & IIIB & IV & \\
\hline WBC & $9850(7777-12000)$ & $10800(8700-13770)$ & 0.034 \\
Hb & $13.25(11.47-14.20)$ & $12.90(11.52-14.20)$ & 0.819 \\
Plt & $295000(232750-351750)$ & $306000(240500-427250)$ & 0.206 \\
\hline
\end{tabular}

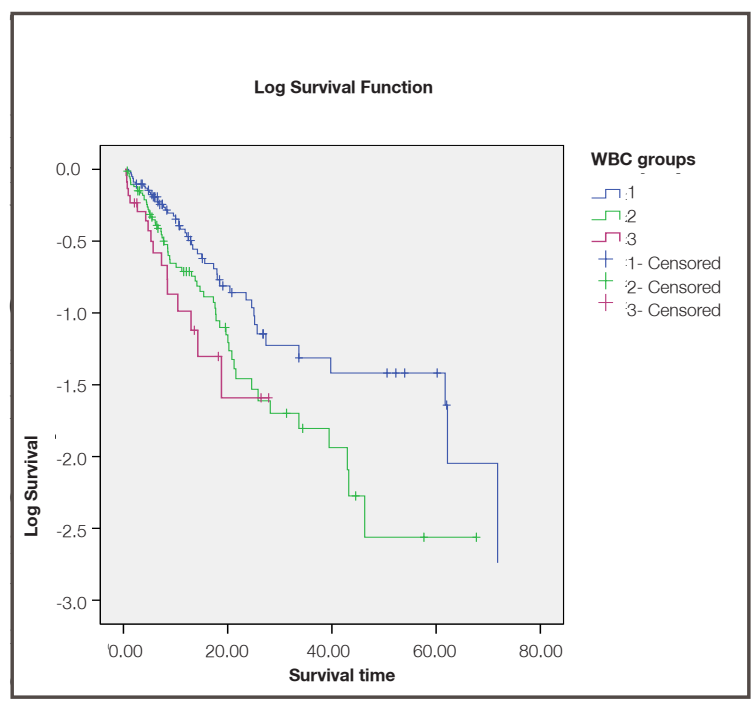

Figure 1. Overall survivals in WBC groups

stage ( $\mathrm{p}$ values were $0.334,0.498,0.384$ and 0.162 respectively). Median OS in these WBC groups were 17.9 months (95\% CI:13.2-22.7) in Group 1, 11.2 months (95\% CI: 5.8-16.6) in Group 2 and 8.4 months (95\% CI: 4.3-12.5) in Group 3. The difference between groups was statistically significant $(\mathrm{p}=$ 0.003) (Figure 1).
Median overall survival values in WBC groups according to stages IIIB and IV are shown in Table 2. There was a trend towards longer OS in patients with lower WBC counts within each stage group, although the difference was not statistically significant (Figure $2 \mathrm{a}$ and $2 \mathrm{~b}$ ). The poorest survivals were detected in the stage IV patients with higher WBC levels, median OS was 5.7 months in patients with WBC levels $>15000$ / $\mathrm{mm} 3$, whereas it was 12.1 months for patients with normal WBC levels $<10000 / \mathrm{mm}^{3}(\mathrm{p}=0.066)$. (Figure 2b)

Median OS was 10.6 months (95\% CI: $5.9-15.3$ ) in patients with anemia $(n=80)$, whereas it was 17.3 months (95\% CI:13.5-21.0) in those without $(\mathrm{n}=106)$ anemia $(\mathrm{p}=0.204)$. Thrombocytosis was detected in $50(26.9 \%)$ of the cases. Patients with thrombocytosis had lower OS [8.5 months (95\% CI: 7.9-9.1)] than those without [15.6 months (95\% CI:11.6-19.6)] ( $\mathrm{p}=$ 0.048).

In univariate analyses age, ECOG-PS of 2 or 3 , stage IV disease, pretreatment hemoglobin and WBC levels were significant for survival. In multivariate analyses, ECOG-PS of 2 or 3, stage IV disease, pretreatment low hemoglobin and high WBC levels were found to be independently associated with poorer OS (Table $3)$.

\begin{tabular}{|lll|}
\hline \multicolumn{2}{|l|}{ Table 2. Median survival values in WBC groups according to stages } \\
\hline \multicolumn{1}{|c|}{ WBC groups } & \multicolumn{1}{c|}{ Median survival (months) } \\
\cline { 2 - 3 } & Stage IIIB & Stage IV \\
\hline $1\left(\leq 10000 / \mathrm{mm}^{3}\right)$ & $39.77(6.48-73.06)$ & $12.1(9.77-14.50)$ \\
$2\left(10001-\leq 15000 / \mathrm{mm}^{3}\right)$ & $19.67(14.92-24.42)$ & $8.5(6.71-10.29)$ \\
$3\left(>15000 / \mathrm{mm}^{3}\right)$ & $10.43(4.86-15.80)$ & $5.70(1.95-9.45)$ \\
\hline
\end{tabular}



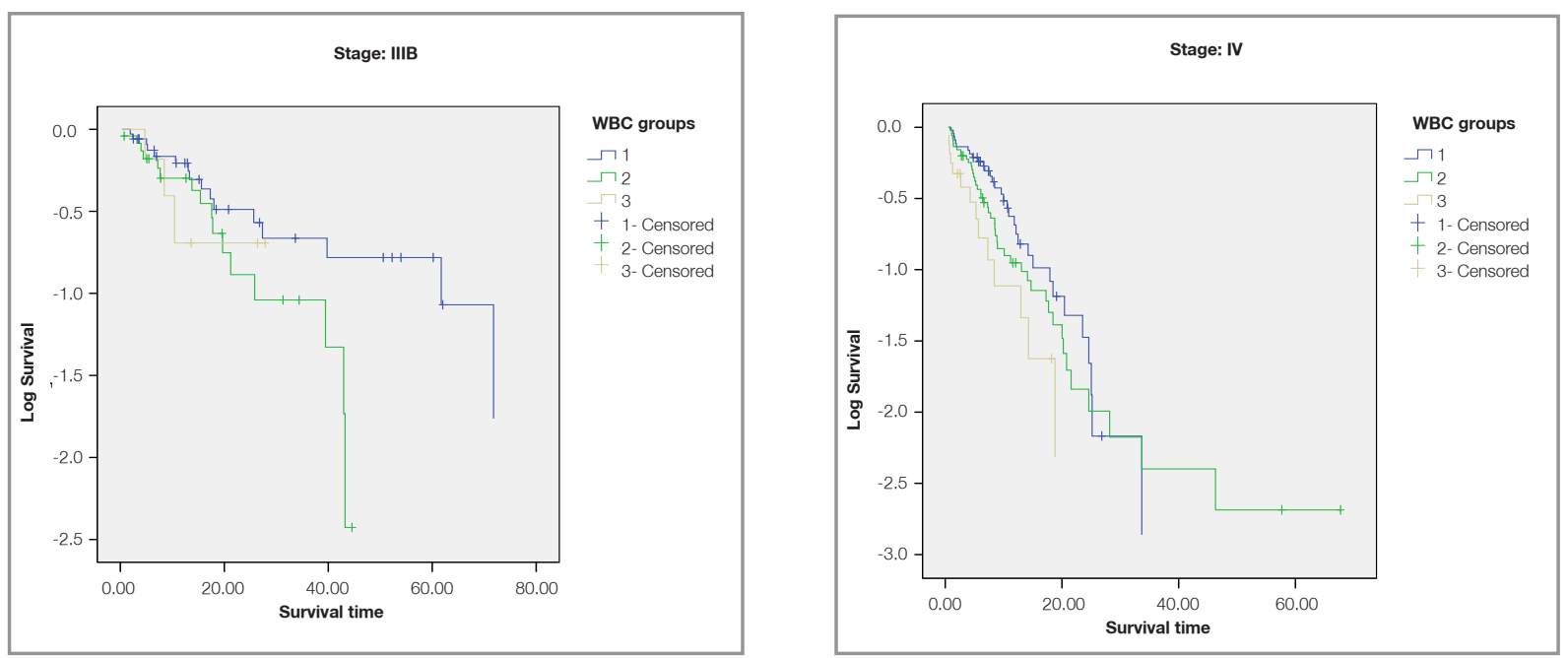

Figure 2. Survivals according to WBC groups, in stage IIIB (A) and in stage IV (B)

\section{DISCUSSION}

In this study, we found that along with classical prognostic factors including disease stage and ECOG-PS, lower hb levels and higher WBC counts were independently associated with poorer OS in patients with stage IIIB-IV NSCLC. Median OS was 25.7 months in stage IIIB and 8.9 months in stage IV disease in our study, consistent with the literature.

Prognostic value of various clinical and laboratory parameters were assessed in previous studies in patients with NSCLC. Hoang et al analysed prognostic factors in chemo-naive advanced NSCLC patients to build a nomogram to predict 1 - and 2-year survivals. Presence of skin or liver metastases, lower performance status, loss of appetite and presence of more than 3 metastatic sites were all found to be poor prognostic factors that predicted 1- and 2-year survival. Hematological parameters were not evaluated. ${ }^{15}$ Similarly in our study, stage IV and poor performance status were shown to be associated with shorter OS. Kasuga et al. investigated the prognostic value of leucocytosis among 227 patients with stage I-IV NSCLC. Patients with leukocytosis at diagnosis or at any time on follow-up had shorter OS than those without (4.6 vs 20.8 months, $\mathrm{p}<0.001)$. They also examined the serum levels of G-CSF, GM-CSF and IL-6 and found that 29 out of 32 patients with tumor related leucocytosis had high levels of at least one of the cytokines. The frequency of tumor related leucocytosis was highest in large cell group compared with adeno and squamous group $\left(54.5 \%, 11.7 \%\right.$ and $20 \%$ respectively). ${ }^{16}$
In our study, although the number of patients with large cell carcinoma was small, the frequency of tumor related leucocytosis was also highest in large cell group (75\%). However no association was found between any histopathological subtype and pretreatment WBC levels $(\mathrm{p}=0.387)$.

Mandrekar et al. performed a pooled data set of 9 North Central CancerTreatment Group trials in 1053 advanced NSCLC patients to examine the impact of pretreatment blood levels (creatinine, hemoglobin, WBC and platelet counts) and other demographical factors on OS and time to progression. Multivariate analysis revealed that stage IV disease $(\mathrm{p}=0.03)$, body mass index $<18.5$ ( $\mathrm{p}=0.0007)$, ECOG-PS $>0$ ( $\mathrm{p}<$ $0.0001)$, low hemoglobin levels $(\mathrm{p}<0.0001)$ and high WBC counts $(p=0.0001)$ were poor prognostic factors for both OS and time to progression. In patients with leucocytosis, the prognosis was particularly poor for stage IV patients, however such a prognostic value in stage IIIB patients was not clearly defined. Presence of anemia and thrombocytosis were significant for both TTP and overall survival in univariate setting, but in multivariate analysis while anemia was still significant, presence of thrombocytosis was not found to be correlated with survival values. ${ }^{17}$ In our study, although anemia and higher pretreatment leucocyte levels were associated with poorer survival in the whole group, this association could not be shown within each stage group, possibly due to type-II error. Also presence of thrombocytosis was not detected to be significant for survival values in multivariate analysis. 


\begin{tabular}{|c|c|c|c|c|}
\hline VARIABLES & $\begin{array}{l}\text { Univariate } \\
\text { HR (95\%Cl) }\end{array}$ & $\mathbf{p}$ & $\begin{array}{l}\text { Multivariate } \\
\text { HR }(95 \% \mathrm{Cl})\end{array}$ & $\mathbf{p}$ \\
\hline Age & $1.22(1.01-1.46)$ & 0.035 & - & - \\
\hline \multicolumn{5}{|l|}{ Gender } \\
\hline Male & 1.00 & - & - & - \\
\hline Female & $1.19(0.71-1.99)$ & 0.509 & - & - \\
\hline \multicolumn{5}{|l|}{ ECOG-PS } \\
\hline 0 & 1.00 & - & 1.00 & - \\
\hline 1 & $1.18(0.76-1.82)$ & 0.463 & $1.16(0.73-1.84)$ & 0.543 \\
\hline 2 & $5.00(2.84-8.80)$ & $<0.001$ & $3.49(1.88-6.48)$ & $<0.001$ \\
\hline 3 & $3.92(2.06-7.46)$ & $<0.001$ & $5.99(3.01-11.91)$ & $<0.001$ \\
\hline \multicolumn{5}{|l|}{ Stage } \\
\hline IIIB & 1.00 & - & 1.00 & - \\
\hline IV & $2.54(1.72-3.78)$ & $<0.001$ & $1.87(1.20-2.91)$ & 0.006 \\
\hline \multicolumn{5}{|l|}{ Smoking } \\
\hline No & 1.00 & - & - & - \\
\hline Yes & $0.90(0.55-1.47)$ & 0.671 & - & - \\
\hline \multicolumn{5}{|l|}{ Subtype } \\
\hline Nos & 1.00 & - & - & - \\
\hline Adeno & $0.77(0.47-1.28)$ & 0.312 & - & - \\
\hline Squamous & $0.81(0.51-1.31)$ & 0.397 & - & - \\
\hline WBC & $1.54(1.27-1.88)$ & $<0.001$ & $1.40(1.14-1.73)$ & 0.001 \\
\hline Hemoglobin & $0.93(0.84-1.02)$ & 0.01 & $0.90(0.82-0.99)$ & 0.029 \\
\hline Plt & $1.16(0.99-1.34)$ & 0.061 & - & - \\
\hline
\end{tabular}

Paesmans et al studied prognostic factors for survival in 1052 advanced NSCLC patients. They confirmed their results by application of recursive partitioning and amalgamation algorithms (RECPAM) and classified patients into 4 subgroups according to estimated median survival times. In this classification, only abnormal WBC and neutrophil counts were shown to be poor prognostic for survival. Thrombocytosis was not shown to be correlated with survival values. ${ }^{14}$ However in the study by Tomita et al. it was shown that the presence of preoperative anemia, leucocytosis and thrombocytosis, when found together, was associated with worse 5 year survival rates compared with those without any of these abnormal cell counts in resectable NSCLC patients (5 year survivals $25.0 \%$ vs $78.2 \%$, respectively). ${ }^{18}$ Another study showed that presence of anemia alone was associated with decreased relapse free survival and OS $(\mathrm{p}=0.02$ and 0.026 respectively) for NSCLC patients who were treated by definitive surgery and who did not receive any (neo)adjuvant treatment. ${ }^{3}$

In a recent study, the prognostic value of pretreatment hemoglobin, WBC and platelet levels were investigated in a cohort of patients with stage I-IV NSCLC who received curatively intended radiotherapy. Both seperately and all possible combinations of abnormal results of these 3 blood parameters were associated with poor prognosis, and it was shown that when more than one marker was abnormal, the negative prognostic value increased noticeably. Median survivals were 16 months for patients without abnormal levels in any of these 3 blood counts and 8 months for those with abnormal results in all 3 counts ( $\mathrm{p}<$ 0.0001 ). It was concluded that standard haematological variables might be used in the patient-based decision making regarding treatment. ${ }^{19}$

Besides the presence of tumor related leucocytosis, a pooled analysis of an Italian group data from about 
1300 advanced stage NSCLC patients described the prognostic role of mild and severe chemotherapy induced neutropenia. In this analysis, 53\% of the cases had experienced at least one episode of neutropenia of any grade. Mild and severe neutropenia were found to be significant prognostic factors with hazard ratios of death as 0.74 (95\% CI: 0.56-0.98) and 0.65 (95\% CI: 0.46-0.93) respectively. ${ }^{20}$ Also Pallis et al. suggested that chemotherapy induced neutropenia was an independent prognopstic factor for survival. ${ }^{21}$ Later Maione et al. hypothesized if the prognostic value of chemotherapy induced neutropenia being affected by the presence of tumor related leucocytosis and if these two groups were in fact the representatives of the same population..$^{22}$ But this is still an era to be lightened by prospective trials.

In conclusion, hematological parameters including WBC counts or hb levels can be used as prognostic factors in patients with advanced NSCLC. Being simple, cheap and widely available, these factors may aid in tailoring treatment according to subgroups or in risk stratification in clinical trials. In the light of these findings, future prospective trials evaluating the predictive value of these blood parameters on the chemotherapy regimens may be useful for tailoring the treatment in each case.

\section{REFERENCES}

1. Siegel R, Naishadham D, Jemal A. Cancer statistics, 2012. CA Cancer J Clin 62: 10-29, 2012.

2. Howlader N, Noone A, Krapcho M. SEER Cancer statistics review, 1975-2009 based on November 2011 SEER data submission. National Cancer Institute, Bethesda, MD, 2012.

3. Yovino S, Kwok Y, Krasna M, et al. An association between preoperative anemia and decreased survival in early stage non small cell lung cancer patients treated with surgery alone. Int J Radiat Oncol Biol Phys 62: 1438-1443, 2005.

4. Brundage MD, Davies D, Mackillop WJ. Prognostic factors in non small cell lung cancer: a decade of progress. Chest 122: 1037-1057, 2002.

5. Finkelstein DM, Ettinger DS, Ruckdeschel JC. Long term survivors in metastatic non small cell lung cancer: an Eastern Cooperative Oncology Group Study. J Clin Oncol 4: 702-709, 1986.

6. Efficace F, Bottomley A, Smit EF, et al. EORTC Lung Cancer Group and Quality of Life Unit. Is a patient's self-reported health related quality of life a prognostic factor for survival in non-small cell lung cancer patients? A multivariate analysis of prognostic factors of EORTC study 08975. Ann Oncol 17: 1698-1704,2006.
7. Sequist LV, Joshi VA, Janne PA, et al. Response to treatment and survival of patients with non-small cell lung cancer undergoing somatic EGFR mutation testing. Oncologist 12: 90-98, 2007.

8. Thomson SP, Kessler JF, Miller TP. Leucocyte concentrations in discrimination of benign from malignant lung lesions. Am J Med 80: 1035-1040, 1986.

9. Inoue M, Minami M, Fujii Y, et al. Granulocyte colony-stimulating factor and interleukin-6 producing lung cancer cell line, LCAM. J Surg Oncol 64: 347-350, 1997.

10. Sawyers CL, Golde DW, Quan S, Nimer SD. Production of granulocyte-macrophage colony-stimulating factor in two patients with lung cancer, leucocytosis and eosinophilia. Cancer 69: 1342-1346, 1992.

11. Oshika $Y$, Nakamura $M$, Hatanaka $H$, et al. A human lung cancer xenograft producing granulocyte-colony stimulating factor and parathyroid hormone related protein. Oncol Rep 5: 359362, 1998.

12. Takigawa N, Segawa Y, Okahara M, et al. Prognostic factors for patients with advanced non small cell lung cancer univariate and multivariate analyses including recursive partitioning and amalgamation. Lung Cancer 15: 67-77, 1996.

13. Watine J. Further comments on 'A practical prognostic index for inoperable non small cell lung cancer': a clinical biologist's point of view. J Cancer Res Clin Oncol 124: 581-583, 1998.

14. Paesman M, Sculier JP, Libert P, et al. Prognostic factors for survival in advanced non small cell lung cancer: univariate and multivariate analyses including recursive partitioning and amalgamation algorithms in 1052 patients. J Clin Oncol 13: 1221-1230, 1995.

15. Hoang $T, X u$ R, Schiller JH, et al. Clinical model to predict survival in chemonaive patients with advanced non small cell lung cancer treated with third generation chemotherapy regimens based on Eastern Cooperative Oncology Group data. J Clin Oncol 23: 175-183, 2005.

16. Kasuga I, Makino S, Kiyokawa H, et al. Tumor-related leucocytosis is linked with poor prognosis in patients with lung carcinoma. Cancer 92: 2399-2405, 2001.

17. Mandrekar SJ, Schild SE, Hillman SL, et al. A prognostic model for advanced stage non small cell lung cancer. Pooled analysis of North Central Cancer Treatment Group trials. Cancer 107: 781-792, 2006.

18. Tomita M, Shimizu T, Hara M, et al. Preoperative leukocytosis, anemia and thrombocytosis are associated with poor survival in non-small cell lung cancer. Anticancer Res 29: 2687-2690, 2009.

19. Holgersson G, Sandelin M, Hoye E, et al. Swedish lung cancer radiation study group: the prognostic value of anemia, thrombocytosis and leukocytosis at time of diagnosis in patients with non-small cell lung cancer. Med Oncol 29: 31763182, 2012.

20. Di Maio M, Gridelli C, Gallo C, et al. Chemotherapy induced neutropenia and treatment efficacy in advanced non-small cell lung cancer: a pooled analysis of three randomised trials. Lancet Oncol 6: 669-677, 2005. 
21. Pallis AG, Agelaki S, Kakolyris S, et al. Hellenic Oncology Research Group(HORG). Chemotherapy induced neutropenia as a prognostic factor in patients with advanced non small cell lung cancer treated with front line docetaxel-gemcitabine chemotherapy. Lung Cancer 62: 356-363, 2008.

22. Maione P, Rossi A, Di Maio M, Gridelli C. Tumor-related leucocytosis and chemotherapy induced neutropenia: Linked or independent prognostic factors for advanced non-small cell lung cancer? Lung Cancer 66: 8-14, 2009.

\section{Correspondence}

Dr. Arzu OGUZ

Baskent Üniversitesi Tıp Fakültesi

Tıbbi Onkoloji Bölümü

Bahçelievler

Ankara/TURKEY

Phone: +905064546990

Fax: (+90312) 2152509

e-mail: oguzarzu@yahoo.com 